Центр воєнно-стратегічних досліджень Національного університету оборони України імені Івана Черняховського, Київ

\title{
Моделі та процеси життсвого циклу інформаційної системи управління оборонними ресурсами
}

Резюме. У статті проаналізовано життєвий цикл інформаційної системи управління оборонними peсурсами (Defense Resources Management Information System - DRMIS), яка призначена для забезпечення органів військового управління інформаційно-аналітичною підтримкою прийняття рішень щодо управління оборонними ресурсами за функціональними напрямами. Розглянуто моделі та процеси життєвого циклу DRMIS, які відповідають регламентам міжнародних стандартів STANAG та ISO/ДСTУ. Запропоновано комбіновану модель життевого циклу, визначено ії переваги та вимоги до супроводження.

Ключові слова: управління оборонними ресурсами; інформаційна система; міжнародні стандарти; життєвий цикл; модель життєвого циклу.

Постановка проблеми. Оборонна реформа, яка триває в Збройних Силах України, передбачає впровадження сучасних інформаційних систем (IC), стандартів, доктрин i рекомендацій НАТО щодо управління військами, оборонними ресурсами та проведення оборонного планування. Одним iз пріоритетних напрямів, направлених на підвищення ефективності оборонного планування та управління оборонними ресурсами є впровадження IC управління оборонними ресурсами (Defense Resources Management Information System - DRMIS) [1]. Метою DRMIS $€$ забезпечення органів військового управління інформаційноаналітичною підтримкою прийняття рішень у сфері управління оборонними ресурсами за функціональними напрямами: особовий склад, організаційна структура, оборонне планування, матеріально-технічне забезпечення, медичне забезпечення, закупівлі, майно, фінанси та бюджет, адміністративна діяльність.

Зважаючи на принцип відкритості у сфері стандартизації, стандарти НАТО розробляються тільки у випадках, коли не існує відповідного цивільного стандарту. Цей принцип потребує під час супроводження DRMIS враховувати вимоги стандартів Інституту інженерів 3 електротехніки та електроніки (IEEE), Міжнародної організації зі стандартизації (ISO), Інституту технологій розроблення програмного забезпечення (Software Engineering Institute, SEI), згоду на обов'язковість дотримання яких підтверджено вищим законодавчим органом України. Відповідно до вимог цих міжнародних стандартів, супроводження інформаційних систем організовується за вибраною моделлю життєвого циклу (ЖЦ), яка зі свого боку описується відповідними процесами [2]. Отже, наукове обгрунтування вибору моделі ЖЦ DRMIS, визначення процесів, дій і завдань іiі супроводження 3 урахуванням вимог $i$ регламентів нових міжнародних стандартів у галузі інформаційних технологій серії ISO, $\epsilon$ актуальним завданням упровадження DRMIS в Збройних Силах України.

Аналіз останніх досліджень i публікацій. Питання супроводження IC досліджуються як у роботах вітчизняних, так i іноземних фахівців. Так, автори [4] розглядають воєнно-наукове супроводження IC військового призначення на шести етапах ЖЦ: задум, проєктування, виготовлення, експлуатація, модернізація, утилізація. У роботі [5] розглядаються питання інтеграції різнорідних IC управління оборонними ресурсами на етапах проєктування i експлуатації. Розробник теорії i практики адаптивного моделювання (Agile Modeling) Скотт Амблер (Scott W. Ambler) [7] обгрунтовує модель ЖЦ IC, яка має чотири взаємозалежних рівні, відповідно до іiі функціональних складових i методу супроводження: програмне забезпечення (розроблення i розгортання програмних систем), апаратне забезпечення (розроблення, розгортання, підтримка, модернізація), інформаційні технології (уся діяльність підрозділу інформаційного забезпечення), організація бізнес-процесів (діяльність організації загалом).

Проте у цих роботах не враховано вимоги i регламенти нових міжнародних стандартів у галузі інформаційних технологій cepiï ISO, які впровадженні в Україні протягом 2015 - 2019 років, насамперед, щодо 
впровадження системи менеджменту, адаптивних моделей та процесів супроводження ЖЦ IC.

Метою статті $\epsilon$ вибір моделі життєвого циклу DRMIS, визначення процесів, дій і завдань іiі супроводження, що відповідають регламентам нових міжнародних стандартів ISO/IEC/IEEE/STANAG, які діють в Україні [2, 8-19] та чинних національних стандартів ДСТУ.

Виклад основного матеріалу дослідження. Згідно з Концепцією [6], до складових IC Збройних Сил України належать:

система оперативного (бойового)

управління, зв'язку, розвідки та спостереження (C4ISR);

інформаційна система управління оборонними ресурсами (DRMIS);

інформаційна система управління оборонним плануванням (ІСУОП) на основі спроможностей (Capability-Based Defense Planning - CDP);

комплексна система захисту інформації, служби інформаційної безпеки та підтримки інформаційної інфраструктури;

інформаційна інфраструктура на основі сервіс-орієнтованої архітектури (тестове та продуктивне середовища);

система забезпечення сумісності та інтеграції DRMIS, ICУOП та C4ISR.

Отже, DRMIS $\epsilon$ однією 3 основних складових елементів IC Збройних Сил України.

Під DRMIS розумітемо систему обробки інформації та відповідні організаційні ресурси: людські, технічні, фінансові та інші, які забезпечують органи військового управління інформаційно-аналітичною підтримкою прийняття рішень у сфері управління оборонними ресурсами за функціональними напрямами [1]. Невід'ємними компонентами DRMIS є дані, технічне, програмне, інформаційне, лінгвістичне та організаційне забезпечення. За способом реалізації та функціональності DRMIS належить до програмної системи i апаратної системи [13]. За різними класифікаційними ознаками DRMIS $\epsilon$ : автоматизованою системою [14, 15], інформаційною системою [18], комунікаційною системою [17], системою оброблення інформації $[16,18]$.

$$
\text { Технічні вимоги до DRMIS }
$$

регламентують виконання таких завдань [6]: менеджемент ЖЦ DRMIS (DRMIS Life

Cycle Management, LCM), який передбачає ii динамічний розвиток і оновлення архітектури та організаційної структури;

удосконалення (підвищення надійності) DRMIS на основі впровадження новітніх та перспективних інформаційних (інформаційнотелекомунікаційних) технологій та практичної реалізації проєктних рішень на основі визначених вимог;

модифікація та автоматизація функцій наявних елементів DRMIS за призначенням;

створення єдиного інформаційного середовища для забезпечення автоматизованої інформаційної взаємодії елементів DRMIS всіх рівнів.

Зі свого боку, менеджмент DRMIS LCM включає такі основні завдання [2]:

вибір моделі ЖЦ;

розроблення методології (методики) супроводження вибраної моделі ЖЦ.

Модель ЖЦ визначає основні групи nроцесів (Primary Process Group), фази та принципи переходу між ними і описується через прочеси (Process), dii (Advices) ma завдання(Tasks), які охоплюють період життя DRMIS від визначення технічних вимог до припинення iï експлуатації. Методологія (сукупність методик) супроводження ЖЦ визначає порядок проведення комплексу робіт зі супроводження DRMIS, їх детальний зміст (технологічні карти), функціональні обов'язки і відповідальність фахівців для всіх процесів вибраної моделі ЖЦ, рекомендує до впровадження кращі практики (Best practices), направлені на максимально ефективне використання DRMIS [2].

Розглянемо підходи до вибору моделі ЖЦ DRMIS, які базуються на вимогах стандартів ДСТУ/ISO.

Функціональне призначення DRMIS визначає високорівневу архітектуру ЖЦ, яка будується як набір складових елементів - груn процесів, процесів, дій $i$ завдань та взаємних зв'язків між ними. Вибір моделі ЖЦ уявимо як структурну декомпозицію складових елементів, яка будується на принципах:

$$
\text { модульності (ЖЦ DRMIS }
$$

розглядається як система, всі складові елементи (процеси) якої взаємозв'язані 3 урахуванням як внутрішніх, так i зовнішніх факторів, задачі в процесах функціонально зв'язані, а зв'язок між процесами - мінімальний; якщо задача використовується більше, ніж одним процесом, вона сама є процесом; якщо процес $Y$ використовується лише процесом $X$, то процес $Y$ належить до процесу $X$, $є$ його 
частиною або його задачею, за винятком випадків потенційного використання процесу $Y$ іншими процесами в майбутньому) [10];

відповідальності (за кожний процес несе відповідальність особа, яка керує i/aбо контролює його, визначена для заданого життєвого циклу, наприклад, у вигляді ролі в проєктній команді; функція, частини якої знаходяться в компетенції різних осіб, не може розглядатися як самостійний процес).

Декомпозицію складових елементів ЖЦ DRMIS наведено на рис. 1. Під час декомпозиції важливо забезпечити можливість застосування для кожного складового елементу ЖЦ застосування окремого PDCA-циклу (спіралі якості Демінга) [20]: планування (Plan), виконання (Do), перевірка (Check), реакція (Act).

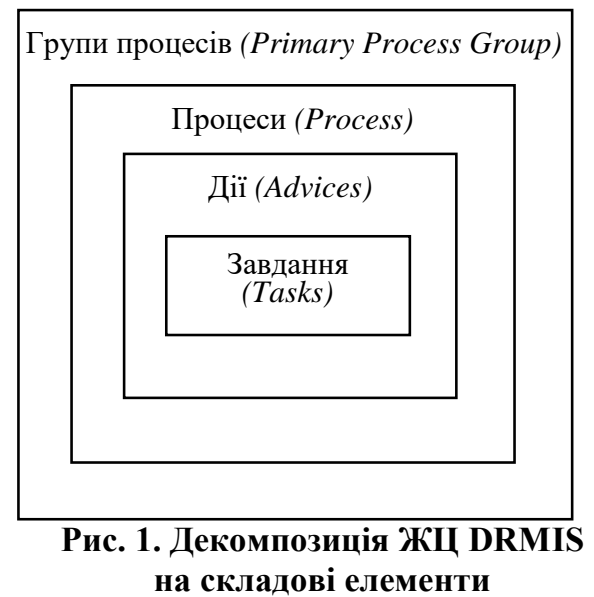

Групи процесів (Processes) включають: основні (Primary), допоміжні (Supporting) i організаційні (Organizational) [2]. Основні та допоміжні процеси виконуються одночасно, організаційні процеси діють упродовж усього ЖЦ і зв’язані 3 основними процесами, що обгрунтовує вибір моделі ЖЦ тільки за основними процесами.

До групи основних проиесів належать:

замовлення (Acquisition) - дії і завдання замовника;

постачання (Supply) - діï i завдання постачальника, який забезпечує замовника програмним продуктом або послугою;

розроблення (Development) - роботи зі створення DRMIS і іï компонентів відповідно до заданих вимог, зокрема оформлення проєктної та експлуатаційної документації, підготовку матеріалів, необхідних для перевірки працездатності та відповідної якості програмних продуктів, матеріалів для організації навчання персоналу тощо, як правило, передбачає аналіз, проєктування i реалізацію; експлуатація (Operation) - роботи 3 впровадження компонентів DRMIS в експлуатацію, зокрема конфігурацію БД i робочих місць користувачів, розроблення експлуатаційної документації, навчання персоналу, експлуатацію, локалізацію проблем i усунення причин їх виникнення, модифікацію DRMIS в рамках встановленого регламенту, підготовку пропозицій щодо вдосконалення, розвитку та модернізації системи;

супроводження (Maintenance) - діï i завдання, які виконуються супроводжуючою організацією, тобто службою супроводження, внесень змін до ПЗ для виправлення помилок, підвищення продуктивності або адаптації до умов, які змінилися, роботи або вимог.

До введення в дію регламенту [2], основні процеси, як правило, розглядалися як незмінні фази ЖЦ.

До групи допоміжних прощесів належать:

документування (Documentation) формалізований опис інформації, створеної протягом ЖЦ DRMIS;

управління конфігурацією (Configuration Management) - застосування адміністративних i технічних процедур протягом ЖЦ для визначення стану компонентів DRMIS, управління їі модифікаціями;

верифікація (Verification) - визначення того, що програмні продукти, які $\epsilon$ результатами певної дії, повністю відповідають вимогам або умовам, зумовленим попередніми діями;

атестація (Validation) - визначення повноти відповідності заданих вимог i створеної системи їх конкретному функціональному призначенню;

сумісне оцінювання (Joint Review) оцінювання стану робіт за проєктом: контроль планування i управління ресурсами, персоналом, апаратурою, інструментальними засобами;

вирішення проблем (Problem Resolution) - аналіз і вирішення проблем, незалежно від їх походження або джерела, які виявлені під час розроблення, експлуатації, супроводження або інших процесів.

До групи організаційних прочесів належать:

управління (Management) - дії i завдання, які можуть виконуватися будь-якою стороною, яка управляє своїми процесами;

створення інфраструктури (Infrastructure) - вибір і супроводження технологіï, стандартів та інструментальних 
засобів, вибір та установка апаратних i програмних засобів, які використовуються для розроблення, експлуатації або супроводження DRMIS ;

удосконалення (Improvement) оцінювання, вимірювання, контроль i удосконалення процесів ЖЦ;

навчання (Training) - початкове навчання i подальше постійне підвищення кваліфікації персоналу.

Кожен процес включає низку дій (Advices). Наприклад, процес супроводження включає інсталяцію, настройку системи для користувачів згідно 3 технічною документацією, виконання регламентів 3 обновлення, підтримки і відновлення даних, розроблення навчальних матеріалів для користувачів з експлуатації DRMIS.

Кожна дія включає низку завдань. Наприклад, підготовка заявочних пропозицій має передбачати формування вимог до системи; формування списку програмних продуктів; встановлення умов і угод; опис технічних обмежень; стадії життєвого циклу IC, взаємозв'язок між процесами і стадіями.

Регламенти $[2,11,12]$ дають змогу для опису ЖЦ IC використання таких моделей [8]: каскадна (послідовна), еволюційна (ітераційна), спіральна, інкрементна (нарощування функцій), комбінована (змішана).

3 урахуванням об'єктивних умов впровадження DRMIS в Збройних Силах України (порядок i обсяги фінансування, динамічний $\mathrm{i}$ безперервний розвиток інформаційних технологій, зміна масштабів цілей і завдань щодо управління ресурсами) [3], організаційної та технічної складових процесу реалізації заходів щодо модернізації вже існуючих фрагментів DRMIS [1, 5, 6], раціонально впровадження комбінованої (змішаної) моделі ЖЦ DRMIS, яка за структурою $є$ інкрементною (рис. 2), а 3 огляду на розвиток i вдосконалення еволюційною (рис. 3).

Сутність інкрементної моделі (нарощування функцій за методом “step-bystep”) [8] полягає в реалізації основних базових функцій для досягнення мінімально необхідної функціональності 3 одночасним збереженням властивостей наступного нарощування інших функцій за необхідністю. Перевага підходу - у будь-який момент часу $є$ працююча система, хоч i частково. Впровадження елементів такої моделі дасть змогу: замінити існуючі елементи на сучасну DRMIS 3 використанням новітніх інформаційно-телекомунікаційних технологій 3 перспективою подальшої модернізації, поліпшити сталість, безперервність, гнучкість, оперативність підвищити оперативність реагування органів управління.

Сутність еволюційної моделі [8] полягає у поступовому, безперервному і динамічному нарощуванні спроможностей DRMIS до розрахункових (заданих технічним завданням на проєкт). Така модель потребує остаточного визначення повного обсягу функцій на етапі проєктування, та не передбачає їх зміни у процесі життєвого циклу.

Обмеженнями застосування таких моделей $є$ :

неможливість комбінації готового програмного забезпечення 3 новими розробками програмного забезпечення;

виключення можливості інтеграції 3 наявними інформаційними системами;

В існуючих умовах обмежених ресурсів на розвиток інформаційних систем, такі обмеження є суттєвими.

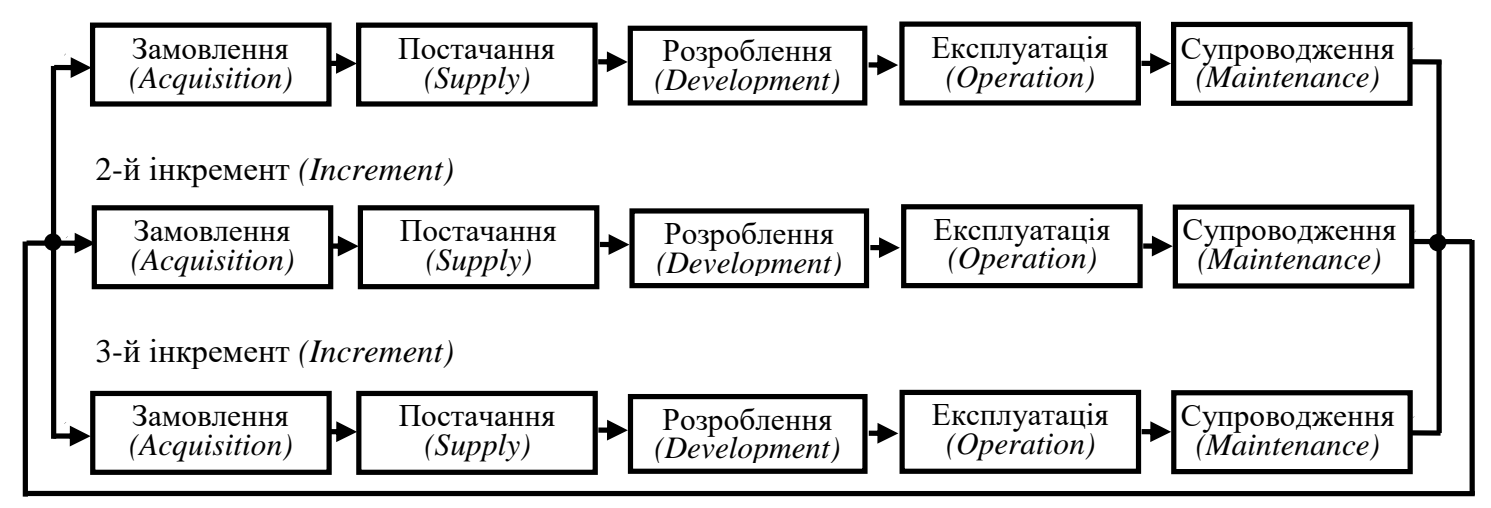

Рис. 2. Інкрементна модель життєвого циклу DRMIS 


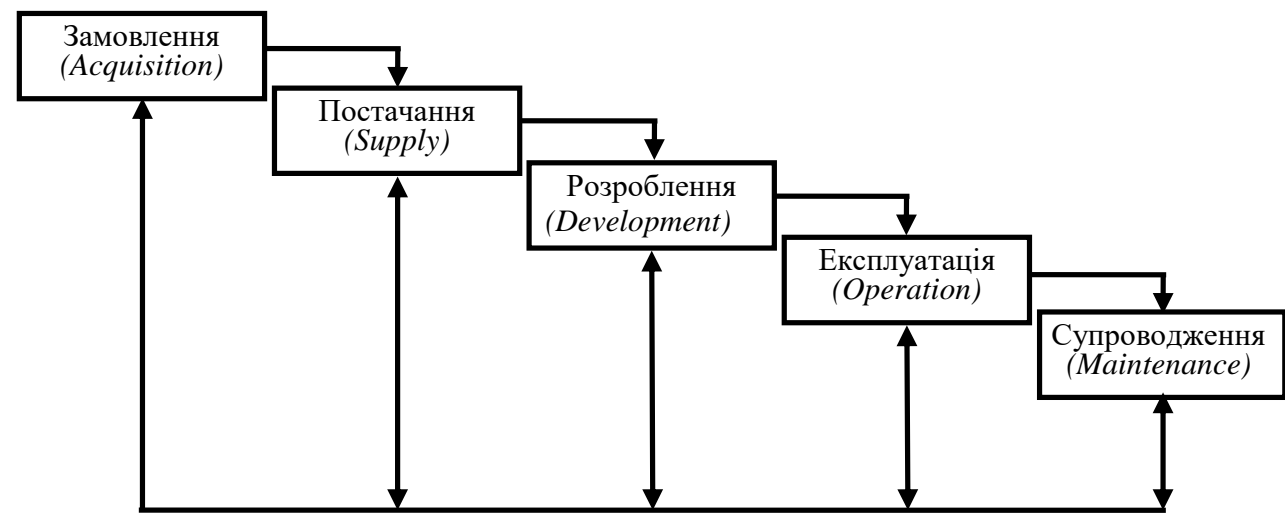

Рис. 3. Еволюційна модель життєвого циклу DRMIS

Водночас, модель ЖЦ DRMIS розробляється для забезпечення того, щоб DRMIS протягом усього періоду експлуатації задовольняла таким вимогам:

сприйнятю замовником ступеня виконання його вимог і очікувань [12];

гарантуванню якості проєктних рішень наявність підтверджувальної документації від розробника (постачальника) для доведення відповідності проєктних рішень установленим вимогам цього документа [13];

відповідальності відповідальних осіб заінтересованих сторін щодо реалізації таких процесів;

відповідності технічним вимогам і технічному завданню;

проєктування (планування i керування проєктом, підготовки проєктних рішень і проєктної документації);

контролю за виконанням проєкту (плану керування проєктом), підготовкою проєктної документації і процесом верифікації;

стандартизації - заходи 3 планування, керування i контролю процесу проєктування щодо модернізації існуючої загальнодержавної системи оповіщення мають відповідати нормативно-правовим актам, вимогам i рекомендаціям національних стандартів;

безперервності та спадкоємності (технологічність, модульність i масштабованість програмних і технічних засобів), а саме: розроблення і вдосконалення функцій мають забезпечувати можливість подальшого розвитку системи 3 використанням сучасних високоефективних інформаційних технологій i програмнотехнічних засобів та має бути забезпечений захист початкових вкладень фінансових, матеріально-технічних і трудових ресурсів;

застосування єдиної для всієї системи технології створення, поновлення, збереження i використання інформаційних ресурсів, зокрема одноразове введення i оброблення даних під час забезпечення багаторазового їх використання;

проєктування функцій системи 3 позиції системного аналізу, об'єктно-орієнтованого підходу та Концепції відомчих програм створення Єдиної автоматизованої системи управління Збройними Силами України, єдиної інформаційної системи управління оборонними ресурсами та інформаційної інфраструктури [6];

відкритості - відкритість має забезпечуватися шляхом нарощування технічних засобів системи, поновлення i розширення функцій відповідно до іiі розвитку без порушення функціонування та кардинальної зміни їі структури і складу;

інформаційної сумісності (інтеграція 3 іншими інформаційними системами) інтеграція має бути організована на основі стандартів взаємозв'язку відкритих систем відповідно до встановлених протоколів обміну даними, правил i регламентів для забезпечення інформаційної взаємодії;

інформаційної безпеки - забезпечення необхідного рівня конфіденційності, кіберзахисту, цілісності, доступності, автентичності та достовірності інформації і ефективності технічного захисту інформаційного ресурсу системи від втрат, спотворення, руйнування і несанкціонованого використання;

мобільності (здатність до адаптації, простота установки, взаємозамінність) забезпечення результативності та ефективності переносу системи, програмного продукту або компонента 3 однієї апаратної, програмної чи іншої експлуатаційної платформи (використовуваного середовища) в іншу (інше);

ефективності - вибір проєктних (програмних, технічних) рішень щодо подальшого розвитку DRMIS має забезпечувати мінімізацію витрат фінансових, матеріально-технічних та трудових ресурсів 
під час забезпечення досягнення необхідних спроможностей інформаційної системи.

Для забезпечення цього переліку вимог пропонується застосування комбінації інкрементної і еволюційної моделей ЖЦ DRMIS.

Сутність комбінованої моделі полягає у проведенні декомпозиції ЖЦ DRMIS на складові елементи з наступним забезпеченням можливості їх доповнення (оптимізації) за необхідністю відповідно до результатів проведення PDCA аналізу. Така модель повністю відповідає регламентам STANAG та ISO [2, 8-11] i забезпечує можливість доповнення (нарощування) або скорочення необхідних функцій і компонентів на будьяких наступних етапах.

Евристичним методом встановлено, що застосування комбінованої моделі ЖЦ DRMIS може забезпечити:

визначення тільки основних можливостей системи на початковому етапі, що запобігає формуванню громіздкого переліку вимог;

можливість оцінювання найважливіших функціональних особливостей системи на більш ранніх етапах розроблення і зниження ризику невдачі, перегляду і зміни вимог;

розподіл системи на компоненти, які додаються (нарощуються) у процесі іiі впровадження, дає змогу об'єднати отриманий досвід у вигляді вдосконаленого компонента та використовувати до того ж набагато менше ресурсів і часу на розроблення;

можливість керованого розподілу ресурсів 3 урахуванням важливості реалізованих в інкременті функцій, тобто залучення тільки окремих ресурсів у разі необхідності;

реалізацію процесів експлуатації та супроводження системи паралельно 3 процесом розроблення;

сумісність 3 наявними інформаційними та автоматизованими системами;

використання сервіс-орієнтованої інтеграційної платформи закордонного або вітчизняного розробника для розроблення нових інтегрованих програмно-технічних рішень.

Водночас, впровадження комбінованої моделі ЖЦ DRMIS, як i міжнародних регламентів STANAG i ISO у процесі супроводженні DRMIS, потребує розв'язання суміжних питань, а саме:

удосконалення нормативно-правової бази 3 питань створення, впровадження, експлуатації, супроводження DRMIS;

створення організаційних структур, відповідальних за повний ЖЦ системи; удосконалення системи підготовки фахівців з питань застосування та експлуатації автоматизованих (інформаційних) систем військового призначення;

розроблення уніфікованих програмнотехнічних платформ i спеціального програмного забезпечення;

введення нових функціональних процедур (сервісів);

підключення національних інформаційних ресурсів і збільшення кількості користувачів;

формування єдиних правил, політик i стандартів технічної та інформаційної сумісності автоматизованих інформаційних систем і їх компонентів, зокрема врахування стандартів НАТО щодо побудови та розвитку комунікаційних та інформаційних систем;

упровадження аналізу та планування за майбутніми сценаріями i операціями сил оборони в термінах спроможностей.

Висновки. Раціональним варіантом моделі ЖЦ DRMIS є комбінований підхід 3 використанням сервіс-орієнтованої інтеграційної платформи закордонного або вітчизняного розробника для розроблення нових інтегрованих програмно-технічних рішень за неавтоматизованими функціональними напрямами і забезпечення сумісності 3 наявними інформаційними та автоматизованими системами.

Реалізація зазначеного варіанта моделі ЖЦ дозволяє комбінацію як готового програмного забезпечення систем класу DRMIS закордонного або вітчизняного розробника, так i розроблення нового програмного забезпечення окремо за кожним функціональним напрямом управління ресурсами, впровадження програмнотехнічних рішень інтеграції нових і наявних інформаційних систем.

У подальших дослідженнях для підтвердження отриманих емпіричних висновків планується проведення математичного моделювання різних підходів до вибору моделі життєвого циклу DRMIS.

\section{СПИСОК ВИКОРИСТАНОЇ ЛІТЕРАТУРИ}

1. Концепція інформатизації Міністерства оборони України : затв. наказом Міністра оборони України від 17.09.2014 p. № 650 .

2. ДСТУ ISO/IEC 12207:2016. Процеси життєвого циклу програмного забезпечення. [Чинний від 2018-01-01]. Київ, 2017. 97 с. (Інженерія систем і програмних забезпечення).

3. Дєнєжкін М. М. Управління оборонними ресурсами: методичний підхід до визначення потреби в ресурсах на розвиток Збройних Сил у ході оборонного планування // Наука i техніка Повітряних Сил Збройних Сил України. Харків, 2018. № 1. С. 123-129. URL: http://nbuv.gov.ua/UJRN/Nitps_2018_1_19. 
4.Питання воєнно-наукового супроводження створення інформаційних систем військового призначення / О.С. Левшенко [та ін.] // Збірник наукових праць Центру воєнно-стратегічних досліджень Національного університету оборони України імені Івана Черняховського. Київ, 2016. № 2 (57). С. 61-66.

5. Кірпічніков Ю. А, Андрощук О. В., Петрушен М. В., Васюхно C. I. Теоретичні підходи до побудови архітектури інформаційної системи управління оборонними ресурсами на основі сервісноорієнтованої моделі. Збірник наукових праць Центру воєнно-стратегічних досліджень Національного університету оборони Украӥни імені Івана Черняховського. Київ, 2018. № 1 (62). С. 80-85.

6. Концепція відомчих програм створення Єдиної автоматизованої системи управління Збройними Силами України, єдиної інформаційної системи управління оборонними ресурсами та інформаційної інфраструктури на період до 2020 року : затв. Міністром оборони України від 12.05.2018 p.

7. Ambler S., Lines M. Disciplined Agile Delivery: A Practioner's.

8. ДСТУ ISO/IEC TR 10032:2012. Еталонна модель керування даними. [Чинний від 2013-03-01]. Київ, 2013. 48 с. (Інформаційні технологіï).

9. ДСТУ ISO/IEC/IEEE 15288:2016. Процеси життєвого циклу системи. [Чинний від 2018-01-01]. Київ, 2017. 90 c. (Розроблення систем i програмного забезпечення).

$\begin{array}{ccrc}10 \text { ДСТУ ISO/IEC/IEEE } & 15289: 2019 . & \text { Уміст } \\ \text { інформаційних } & \text { об'єктів } & \text { життєвого } & \text { циклу }\end{array}$ (документаціï) (ISO/IEC/IEEE 15289:2017, IDT) [Чинний від 2019-08-01]. Київ, 2019. 24 с. (Інженерія систем і програмних засобів).

Стаття надійшла до редакційної колегії 15.01.2020 засобів). (Інформаційні технологіi). та документація). Москва, 1988. 199 с

11. ДСТУ ISO/IEC TS 24748-1:2018. Керування життєвим циклом. частина 1. Настанови щодо керування життєвим циклом (ISO/IEC TS 247481:2016, IDT) [Чинний від 2018-08-15]. Київ, 2018. 29 с. (Інженерія систем і програмних засобів).

12. ДСТУ ISO/IEC TR 24748-2:2015. Управління життєвим циклом. Частина 2. Настанова щодо застосування ISO/IEC 15288 Процеси життєвого циклу системи. [Чинний від 2018-07-15]. Київ, 2015. 91 с. (Розроблення систем і програмного забезпечення).

13. ДСТУ ISO/IEC/IEEE 24765:2018. Словник термінів. (ISO/IEC/IEEE 24765:2017, IDT) [Чинний від 2018-0815]. Київ, 2018. 37 с. (Інженерія систем і програмних

14. ДСТУ 2226-93. Автоматизовані системи. Терміни та визначення. [Чинний від 1994-01-07]. Київ, 1993. 93 с.

15. ДСТУ 2941-94. Розроблення систем. Терміни та визначення. [Чинний від 1994-12-28]. Київ, 1994. 19 с. (Системи оброблення інформації).

16. ДСТУ ISO/IEC 2382:2017. Словник термінів. [Чинний від 2019-01-01]. Київ, 2017. 36 с.

17. ДСТУ ISO 5127:2018. База та словник термінів. [Чинний від 2019-01-01]. Київ, 2018. 243 с. (Інформація

18. ДСТУ 2938-94 Основні поняття. Терміни та визначення. [Чинний від 1996-01-01]. Київ, 1995. 35 с. (Системи оброблення інформації).

19. ДСТУ ISO/IEC 14764:2014. Процеси життєвого циклу програмного забезпечення. Технічне обслуговування. [Чинний від 2016-01-01]. Київ, 2015. 36 с. (Інженерія програмного забезпечення).

20. Каору И. Японские методы управления качеством.

\section{Models and life cycle processes of the defense resources management information system}

\section{Annotation}

To increase the effectiveness of defense planning in the Armed Forces of Ukraine, information systems (IS) of defense resource management (DRMIS) are being introduced. In accordance with the requirements of international standards, IS support is organized on the basis of the selected life cycle model (LC). The regulations allow the use of the following models: cascading, evolutionary, spiral, incremental. The limitations of the use of such models are the impossibility of combining existing and new software and the complexity of integration with existing IP.

Given the objective conditions for the implementation of DRMIS (the order and amount of funding, dynamic development, changing goals and objectives of planning), the organizational and technical components of the process of modernization of DRMIS fragments, it is proposed to use a combined (mixed) DRMIS LC model, which is incremental in structure and from the point of view of development and improvement - evolutionary.

The essence of the combined model is to carry out the decomposition of the DRMIS LC into constituent elements, with the subsequent provision of the possibility of their addition (optimization) if necessary. Such a model fully complies with the regulations of STANAG and ISO and provides the ability to supplement (increase) or reduce the necessary functions and components at any stage of the life cycle.

Application of the combined DRMIS LC model will provide:

Determining at the design stage only the basic functions of the system;

Reducing the risks of viewing and changing requirements in the life cycle process;

Distribution of the system into components that are built up during its implementation,

Saving resources and time at the development stage;

Managed process of resource allocation taking into account the functions being implemented;

Implementation of operation and maintenance processes in parallel with the development process;

Compatibility with existing IS;

Use of a service-oriented integration platform of a foreign or domestic developer;

Implementation of capability-based defense planning.

Keywords: defense resources management, information system, international standards, life cycle, life cycle model. 